\title{
Karakteristik Antioksidan pada Kelopak Bunga Rosella (Hibiscus sabdariffa Linn.)
}

\author{
Maria Inggrid, Yansen Hartanto dan Jesslyn Fedora Widjaja \\ Program Studi Teknik Kimia, Fakultas Teknologi Industri, Universitas Katolik \\ Parahyangan Bandung \\ Email: inggrid@unpar.ac.id
}

\begin{abstract}
ABSTRAK
Bunga rosella mengandung senyawa bioaktif dengan kadar antosianin yang tinggi. Antosianin termasuk golongan senyawa flavonoid yang dapat berperan sebagai antioksidan alami, mampu menghambat radikal bebas serta dapat mencegah terjadinya degeneratif sel dan penyakit lain. Tujuan penelitian adalah mempelajari pengaruh jenis pelarut dan temperatur pada ekstraksi rosella terhadap aktivitas dan kadar antosianin. Manfaat penelitian ini adalah menerapkan hasil peneliti ekstraksi antioksidan pada rosella bagi dunia usaha. Metode penelitian terdiri dari persiapan bahan baku, ekstraksi antosianin dan analisis. Rosella yang telah dikeringkan diekstraksi masing-masing menggunakan campuran pelarut etanol:air dengan variasi 0:100, 50:50 dan 70:30\% v/v , ekstraksi dilakukan masing-masing pada temperatur $30{ }^{\circ} \mathrm{C}, 45{ }^{\circ} \mathrm{C}$, dan $60{ }^{\circ} \mathrm{C}$. Analisis kimia meliputi penentuan kadar antosianin dengan metode $\mathrm{pH}$ differensial, penentuan aktivitas antioksidan dilakukan dengan metode DPPH (1,1-difenil-2 pikrilhidrazil). Hasil penelitian pada kondisi optimum ekstraksi adalah menggunakan pelarut etanol:air $(50: 50 \mathrm{v} / \mathrm{v})$ pada temperatur $45{ }^{\circ} \mathrm{C}$, kadar antosianin dan rendemen tertinggi masing-masing adalah 88,9 $\mathrm{mg} / \mathrm{L}$ dan 53,2\%. Aktivitas antioksidan tertinggi ditunjukan dengan nilai IC50 yaitu 67,3 ppm. Penentuan kestabilan antosianin dilakukan dengan memberi perlakuan termal pada temperatur $30{ }^{\circ} \mathrm{C}, 45{ }^{\circ} \mathrm{C}$, dan $60{ }^{\circ} \mathrm{C}$, dari persamaan Arhenius diperoleh nilai energi aktivasi $18,3 \mathrm{~kJ} / \mathrm{mol}$.
\end{abstract}

Kata Kunci: Rosella, ekstraksi, pelarut, temperatur, analisis, antioksidan

\section{ABSTRACT}

Roselle contains bioactive compounds and has high quantity of anthocyanin. Anthocyanins, including flavonoid compounds that can be used as natural antioxidants, that has the ability to inhibit free radical reaction, in human body can prevent degenerative cell and various diseases. The objective of this research is to study the effect of solvent and temperature in a batch extraction of roselle to the anthocyanin product. The benefit of this research is to give the transfer of extraction product for the benefit of industry. Method used in this research consisting of the preparation of size reduction of roselle into smallest size followed by drying process, and extraction of roselle. Extraction can be done by two variables, namely ratio ethanol and water of $0: 100 ; 50: 50 ; 70: 30 \mathrm{v} / \mathrm{v}$ respectively and temperature of $30^{\circ} \mathrm{C}, 45^{\circ} \mathrm{C}$ and $60^{\circ} \mathrm{C}$. Analysis anthocyanin content was evaluated by the $\mathrm{pH}$ differential method, and the activity of antioxidant using a method of DPPH (1,1-diphenyl-2picrylhydrazil). The research results can be shown that the optimum condition of temperature $45^{\circ} \mathrm{C}$ and ethanol water ratio of 50:50 followed by total anthocyanin of $88.9 \mathrm{mg} / \mathrm{L}$, and yield content of $53.2 \%$. The highest antioxidant activity indicated by $I_{50}$ value of $67.3 \mathrm{mg} / \mathrm{L}$. The effect of temperature in a batch extraction process followed Arrhenius equation with energy activation of $18.3 \mathrm{~kJ} / \mathrm{mol}$.

Keywords: Roselle, extraction, solvent, temperature, analysis, antioxidant 


\section{PENDAHULUAN}

Rosella (Hibiscus sabdariffa L.) merupakan tanaman famili Malvaceae yang banyak tumbuh di daerah tropis seperti Pulau Jawa dan Kalimantan. Rosella mengandung antosianin yang berperan sebagai antioksidan alami dan dapat menangkal radikal bebas. Antioksidan merupakan senyawa yang dapat mendonorkan elektron pada senyawa oksidan untuk menghambat aktivitas oksidan tersebut. Aktivitas antioksidan dapat dianalisis dengan metode DPPH (1,1-diphenyl-2-picrylhydrazil). DPPH merupakan senyawa radikal bebas yang dapat direduksi dengan menerima atom hidrogen dari antosianin, sehingga menyebabkan perubahan warna dari ungu tua menjadi kuning pucat (Mohamed, 2016), perubahan warna tersebut menunjukkan bahwa sampel yang diuji memiliki aktivitas antioksidan (Sayuti, 2015).

Selain sebagai antioksidan, antosianin juga dapat digunakan sebagai zat warna alami. Antosianin banyak terdapat dalam tanaman, buah-buahan, dan sayur-sayuran. Antosianin berpotensi sebagai pewarna alami yang memberikan warna merah, orange, biru, dan ungu. Antosianin merupakan kelompok flavonoid yang terdiri dari dua cincin benzena yang dihubungkan dengan tiga atom karbon. Struktur antosianin yang terdapat pada rosella adalah sianidin-3-glukosida.

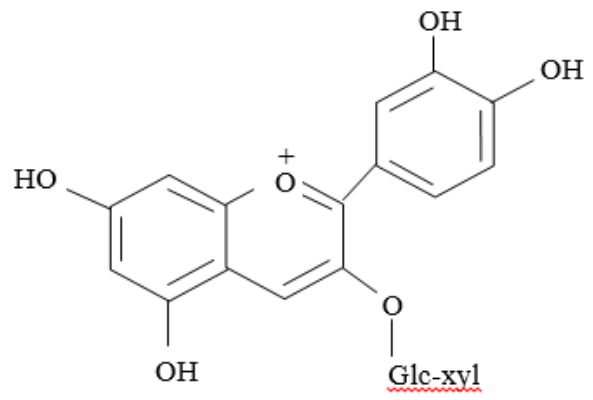

Gambar 1. Struktur antosianin rosella (Aurelio, et al., 2008)

Selama proses pengolahan dan penyimpanan, antosianin dapat teroksidasi akibat perlakuan termal, sehingga antosianin mengalami degradasi. Kestabilan warna antosianin dipengaruhi oleh beberapa faktor, antara lain $\mathrm{pH}$, temperatur dan cahaya. Laju degradasi antosianin cenderung meningkat seiring dengan kenaikan temperatur, sehingga intensitas warna antosianin menurun (Sipahli, 2016).

Antosianin dapat diperoleh dari proses ekstraksi padat cair. Prinsip ekstraksi adalah perpindahan massa komponen zat ke dalam pelarut. Faktor yang mempengaruhi proses ekstraksi adalah ukuran partikel padatan, jenis pelarut, temperatur, pengadukan, waktu ekstraksi, dan rasio zat padat terhadap pelarut. Pelarut yang digunakan harus memenuhi syarat yaitu bersifat selektif, tidak bereaksi dengan bahan, stabil secara kimia dan termal. Pelarut yang digunakan harus memiliki kepolaran yang sesuai dengan senyawa yang akan diekstraksi, senyawa yang polar akan mudah larut ke dalam pelarut yang bersifat polar. Pelarut yang banyak digunakan untuk ekstraksi antosianin yaitu aseton, kloroform, dan metanol, namun penggunaan pelarut tersebut tidak disarankan karena mengandung bahan yang berbahaya jika dikonsumsi, sehingga pada penelitian ini dipilih pelarut etanol dan air yang tidak beracun dan aman untuk digunakan (Hadi, Humam, 2017).

Penelitian yang dilakukan Boeing et al (2014) menunjukan bahwa penggunaan pelarut dapat mempengaruhi kadar antosianin dan aktivitas antioksidan yang diekstraksi. Ekstraksi dengan menggunakan kombinasi pelarut etanol-air akan menghasilkan kadar antosianin dan aktivitas antioksidan lebih tinggi. Gonzales et.al (2012) melaporkan kadar antosianin tertinggi diperoleh pada ekstrak dengan menggunakan pelarut etanol:air $(70: 30 \mathrm{v} / \mathrm{v})$ dan kapasitas antioksidan tertinggi diperoleh dengan pelarut etanol:air $(50: 50 \mathrm{v} / \mathrm{v})$, sedangkan penelitian yang dilakukan oleh Oancea et.al 
(2012) menyatakan pada jenis pelarut yang sama, kenaikan temperatur ekstraksi akan meningkatkan kadar antosianin yang diperoleh. Berdasarkan uraian tersebut, maka perlu dilakukan penelitian terhadap kondisi optimum ekstraksi dengan menggunakan variasi jenis pelarut etanol-air pada sampel kelopak bunga rosella, dan variasi temperatur untuk menghasilkan kadar antosianin dan aktivitas antioksidan yang lebih tinggi, tetapi tidak menyebabkan degradasi.

\section{METODE PENELITIAN}

Pada penelitian ini digunakan bahan serta metode sebagai berikut:

\subsection{Bahan penelitian}

Bahan baku yang digunakan pada penelitian ini yaitu kelopak bunga rosella kering (Hibiscus sabdariffa Linn.) dari Indofun Solution dari Kecamatan Kayen Kidul, Kabupaten Kediri. Bahan kimia yang digunakan untuk analisis adalah DPPH (1,1-difenil-2 pikrihidrazil), larutan buffer $\mathrm{HCl}-\mathrm{KCl} \mathrm{pH}$ 1,0 , buffer natrium asetat- $\mathrm{HCl} \mathrm{pH} 4,5$, sebagai pelarut digunakan etanol teknis $96 \%$ dan air.

\subsection{Metode penelitian}

Kelopak bunga rosella dipotong kecil, dikeringkan sampai kadar air dibawah 10\%. Rosella dimasukkan kedalam ekstraktor batch 1,0 L yang dilengkapi dengan kondensor. Ekstraksi dilakukan menggunakan pelarut etanol:air $(0: 100,50: 50,70: 30 \% \mathrm{v} / \mathrm{v})$ pada temperatur $30,45,60{ }^{\circ} \mathrm{C}$, dengan perbandingan $\mathrm{F}: \mathrm{S}=1: 10$. Ekstrak dan rafinat dipisahkan kemudian dianalisa dengan menggunakan spektrofotometer sinar tampak dan spektrofotometer inframerah.

\subsection{Metode analisis}

Analisis Kadar Antosianin

Kadar antosianin ditentukan dengan metode $\mathrm{pH}$ differential, yaitu penentuan kadar antosianin berdasarkan perubahan struktur molekul antosianin pada $\mathrm{pH}$ 1,0 dan $\mathrm{pH} 4,5$. Absorbansi larutan diukur pada panjang gelombang $520 \mathrm{~nm}$ dan $700 \mathrm{~nm}$ dengan spektrofotometer UV-VIS. Kadar antosianin yang diperoleh ekivalen dengan pigmen antosianin Sianidin-3 glukosida dengan $\mathrm{Mr}=449,2 \mathrm{~g} / \mathrm{mol}, \quad \varepsilon=$ $26900 \mathrm{~L} / \mathrm{mol} . \mathrm{cm}$ (Mahmudatussa'adah, A, et al, 2014).

$\mathrm{A}=\left(\mathrm{A}_{520 \mathrm{~nm}}-\mathrm{A}_{700 \mathrm{~nm}}\right)_{\mathrm{pH} 1,0}-\left(\mathrm{A}_{520 \mathrm{~nm}}-\mathrm{A}_{700 \mathrm{~nm}}\right)_{\mathrm{pH}} 4,5$

\section{Analisis Aktivitas Antioksidan}

Analisis aktivitas antioksidan bunga rosella dilakukan dengan menggunakan metode DPPH. Ekstrak bunga hasil evaporasi dilarutkan dengan etanol pada berbagai konsentasi, ditambahkan larutan DPPH (1:1), kemudian diinkubasi dan diukur absorbansinya pada panjang gelombang $517 \mathrm{~nm}$. Aktivitas antioksidan dihitung dengan rumus

$\%$ Aktivitas antioksidan $=1-\left(\mathrm{A}_{\text {sampel }} / \mathrm{A}_{\mathrm{DPPH}}\right) \times 100 \%$

\section{Kinetika Degradasi}

Pengaruh temperatur terhadap kestabilan dan kinetika degradasi antosianin dilakukan pada temperatur $\left(30,45\right.$, dan $\left.60^{\circ} \mathrm{C}\right)$. Ekstrak dipanaskan dengan menggunakan waterbath yang dilengkapi dengan shaker, kadar antosianin diukur setiap satu jam. 


\section{Kadar antosianin}

\section{HASIL DAN PEMBAHASAN}

Berdasarkan hasil analisis pada Tabel 1, kadar antosianin tertinggi diperoleh pada temperatur $45^{\circ} \mathrm{C}$ dengan pelarut etanol:air $(50: 50 \mathrm{v} / \mathrm{v})$, yaitu sebesar $88,9 \mathrm{mg} / \mathrm{L}$, sedangkan kadar terendah yaitu pada kondisi temperatur $60^{\circ} \mathrm{C}$ dengan pelarut etanol:air $(0: 100 \mathrm{v} / \mathrm{v})$ sebesar $66,8 \mathrm{mg} / \mathrm{L}$. Menurut Boeing et al (2014), ekstraksi dengan menggunakan campuran pelarut organik dan air lebih efektif dibandingkan dengan pelarut air saja. Hal ini disebabkan adanya kesesuaian tingkat polaritas antara antosianin dengan campuran etanol-air, sedangkan pelarut air bersifat sangat polar.

Tabel 1. Pengaruh temperatur dan jenis pelarut terhadap kadar antosianin, $\mathrm{IC}_{50}$, dan rendemen

\begin{tabular}{cccccccccc}
\hline & \multicolumn{2}{c}{$\begin{array}{c}\text { Kadar antosianin } \\
\text { (mg/L) }\end{array}$} & \multicolumn{3}{c}{$\begin{array}{c}\text { IC } \mathbf{5 0} \\
(\mathbf{p p m})\end{array}$} & \multicolumn{3}{c}{$\begin{array}{c}\text { Rendemen } \\
(\%)\end{array}$} \\
\cline { 2 - 10 } $\begin{array}{c}\text { Suhu } \\
\left({ }^{\circ} \mathbf{C}\right)\end{array}$ & \multicolumn{3}{c}{ Pelarut (etanol:air) } & \multicolumn{3}{c}{ Pelarut (etanol:air) } & \multicolumn{3}{c}{ Pelarut (etanol:air) } \\
\cline { 2 - 10 } & $\mathbf{0 : 1 0 0}$ & $\begin{array}{c}\mathbf{7 0 : 3 0} \\
(\mathbf{v} / \mathbf{v})\end{array}$ & $\mathbf{5 0 : 5 0}$ & $\mathbf{0 : 1 0 0}$ & $\mathbf{7 0 : 3 0}$ & $\mathbf{5 0 : 5 0}$ & $\mathbf{0 : 1 0 0}$ & $\mathbf{7 0 : 3 0}$ & $\mathbf{5 0 : 5 0}$ \\
$(\mathbf{v} / \mathbf{v})$ & $(\mathbf{v} / \mathbf{v})$ & $(\mathbf{v} / \mathbf{v})$ & $(\mathbf{v} / \mathbf{v})$ & $(\mathbf{v} / \mathbf{v})$ & $(\mathbf{v} / \mathbf{v})$ \\
\hline 30 & 71,40 & 76,40 & 81,65 & 83,8 & 85,1 & 69,7 & 47,17 & 48,34 & 49,92 \\
\hline 45 & 82,06 & 83,40 & 88,88 & 89,9 & 77,2 & 67,3 & 46,07 & 50,47 & 53,18 \\
\hline 60 & 66,80 & 73,15 & 80,43 & 97,4 & 97,1 & 81,7 & 46,70 & 45,09 & 53,06 \\
\hline
\end{tabular}

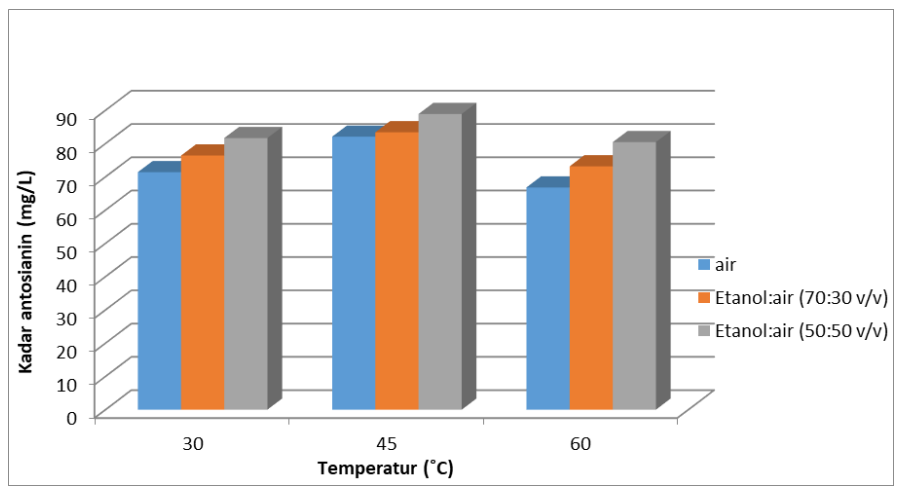

Gambar 1. Grafik kadar antosianin pada berbagai temperatur dan jenis pelarut

Gambar 1 menunjukkan grafik kadar antosianin pada berbagai temperatur dan jenis pelarut. Pada temperatur $60^{\circ} \mathrm{C}$ terjadi penurunan intensitas warna antosianin, sehingga kadar antosianin menurun. Hal ini disebabkan pemanasan pada suhu relatif tinggi dapat menyebabkan sebagian antosianin mengalami degradasi akibat terjadinya hidrolisis pada ikatan glikosidik antosianin, sehingga menghasilkan aglikon yang bersifat tidak stabil dan membuka cincin aglikon, kemudian membentuk gugus carbinol dan chalcone yang tidak berwarna.

\section{Aktivitas antioksidan}

Ekstrak rosella yang direaksikan dengan larutan DPPH akan berubah warna dari ungu menjadi kuning. Aktivitas antioksidan didapatkan dengan membandingkan nilai absorbansi larutan blanko dengan nilai absorbansi sampel, kemudian dihitung nilai $\mathrm{IC}_{50}$. Perolehan nilai $\mathrm{IC}_{50}$ ditunjukkan pada Gambar 2. 


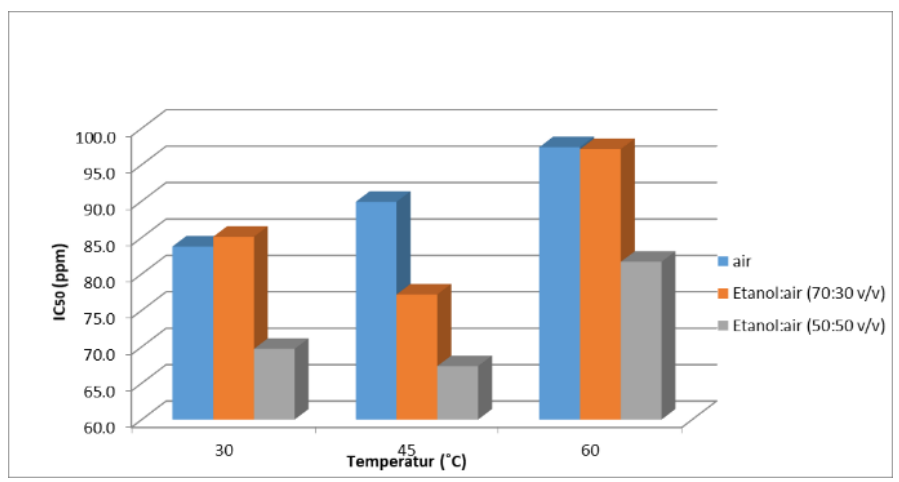

Gambar 2. Grafik Nilai $\mathrm{IC}_{50}$ pada berbagai temperatur dan jenis pelarut

Dari hasil perhitungan, ekstraksi yang dilakukan pada temperatur $45^{\circ} \mathrm{C}$ dengan pelarut etanol:air $(50: 50 \mathrm{v} / \mathrm{v})$ mempunyai nilai $\mathrm{IC}_{50}$ paling kecil yaitu $67,3 \mathrm{ppm}$, semakin kecil nilai $\mathrm{IC}_{50}$ menunjukkan bahwa kemampuan antioksidan untuk meredam radikal bebas semakin besar. Menurut Lase (2013), antioksidan yang kuat mempunyai nilai $\mathrm{IC}_{50}$ antara 50 ppm-100 ppm. Pada temperatur $60^{\circ} \mathrm{C}$ didapatkan nilai $\mathrm{IC}_{50}$ yang paling tinggi, yaitu 97,4 ppm, hal tersebut menunjukkan bahwa kemampuan aktivitas antioksidan untuk meredam radikal bebas semakin berkurang pada temperatur lebih tinggi, karena antosianin yang terekstrak mengalami degradasi (Chumsri et al, 2007).

\section{Rendemen}

Analisis rendemen dilakukan dengan membandingkan massa ekstrak yang dihasilkan terhadap massa sampel rosella yang digunakan saat ekstraksi. Rendemen yang diperoleh pada setiap variasi dapat dilihat pada Gambar 3.

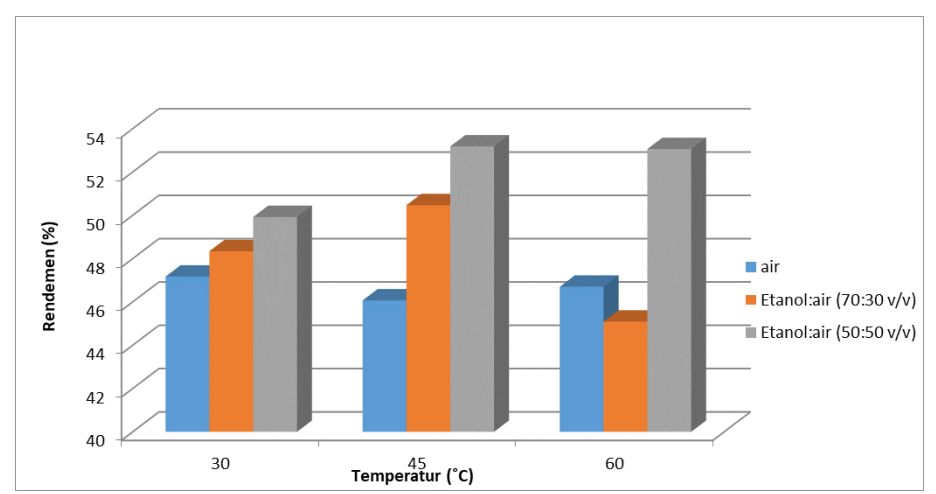

Gambar 3. Perolehan rendemen pada berbagai temperatur dan jenis pelarut

Berdasarkan hasil penelitian, rendemen terbesar diperoleh pada temperatur ekstraksi $45^{\circ} \mathrm{C}$ dengan pelarut etanol:air $(50: 50 \mathrm{v} / \mathrm{v})$, yaitu sebesar 53,2\%. Pada grafik diatas dapat dilihat pada temperatur 45 ${ }^{\circ} \mathrm{C}$ dan $60{ }^{\circ} \mathrm{C}$ rendemen yang diperoleh lebih tinggi dibandingkan temperatur $30^{\circ} \mathrm{C}$. Hal ini menunjukkan pada temperatur lebih tinggi laju difusi meningkat, sehingga komponen dalam bahan lebih mudah terekstraksi (Mastuti et al, 2013). Pada temperatur $60{ }^{\circ} \mathrm{C}$ diperoleh rendemen cukup tinggi, tetapi kadar antosianin dan aktivitas antioksidan relatif lebih rendah. Ekstraksi dengan campuran pelarut etanol-air (1:1) menghasilkan rendemen yang lebih besar dibandingkan dengan pelarut air, karena antosianin bersifat relatif polar, sehingga lebih mudah terekstraksi pada campuran etanol-air dengan polaritas yang sesuai. 


\section{Kinetika Degradasi Antosianin}

Pada proses pengolahan dan penyimpanan, antosianin mudah mengalami degradasi. Kestabilan warna antosianin dipengaruhi oleh beberapa faktor, antara lain $\mathrm{pH}$, temperatur dan cahaya. Laju degradasi antosianin pada penelitian ini diukur pada temperatur $30,45,60{ }^{\circ} \mathrm{C}$. Dengan menggunakan persamaan reaksi kinetika orde 1 (Wu, Hai Yao, et al., 2018), data ln C/Co dialurkan terhadap waktu, diperoleh konstanta laju reaksi pada Tabel 2.

Tabel 2. Pengaruh temperatur terhadap konstanta laju reaksi

\begin{tabular}{cc}
\hline Temperatur $\left({ }^{\circ} \mathbf{C}\right)$ & $\mathbf{k}(\mathbf{m o l} / \mathbf{L} \mathbf{j a m})$ \\
\hline 30 & 0,019 \\
\hline 45 & 0,034 \\
\hline 60 & 0,036 \\
\hline
\end{tabular}

Dari hasil penelitian didapat nilai konstanta laju reaksi makin meningkat dari temperatur pemanasan $30^{\circ} \mathrm{C}$ sampai $60^{\circ} \mathrm{C}$, intensitas warna antosianin pada temperatur $60^{\circ} \mathrm{C}$ menurun, hal ini menunjukkan antosianin mengalami degradasi pada temperatur yang lebih tinggi, struktur antosianin cenderung berubah menjadi carbinol menjadi chalcone tidak berwarna.

\section{Analisa FTIR}

Dari hasil analisis FTIR yang ditunjukkan pada Gambar 4, didapatkan beberapa puncak pada hasil ekstraksi kelopak bunga rosella. Pada ekstrak rosella menunjukkan adanya gugus fenol pada puncak serapan $3302,13 \mathrm{~cm}^{-1}$, gugus $\mathrm{C}=\mathrm{O}$ stretching keton terbaca pada $1735,93 \mathrm{~cm}^{-1}$, gugus $\mathrm{O}-\mathrm{H}$ alkohol terbaca pada $1381,03 \mathrm{~cm}^{-1}$ dan gugus $\mathrm{C}-\mathrm{H}$ alkana (metil) pada $1327,03 \mathrm{~cm}^{-1}$. Gugus C-O-C stretching eter terbaca pada $1087,85 \mathrm{~cm}^{-1}$. Gugus C-O stretching alkohol terbaca pada $1049,26 \mathrm{~cm}^{-1}$. Sedangkan pada 879,54 dan $709,80 \mathrm{~cm}^{-1}$ menunjukan adanya gugus $\mathrm{C}-\mathrm{H}$ aromatik. Berdasarkan hasil spektrum FTIR dapat disimpulkan bahwa dalam ekstrak kelopak bunga rosella mengindikasikan adanya senyawa antosianin.

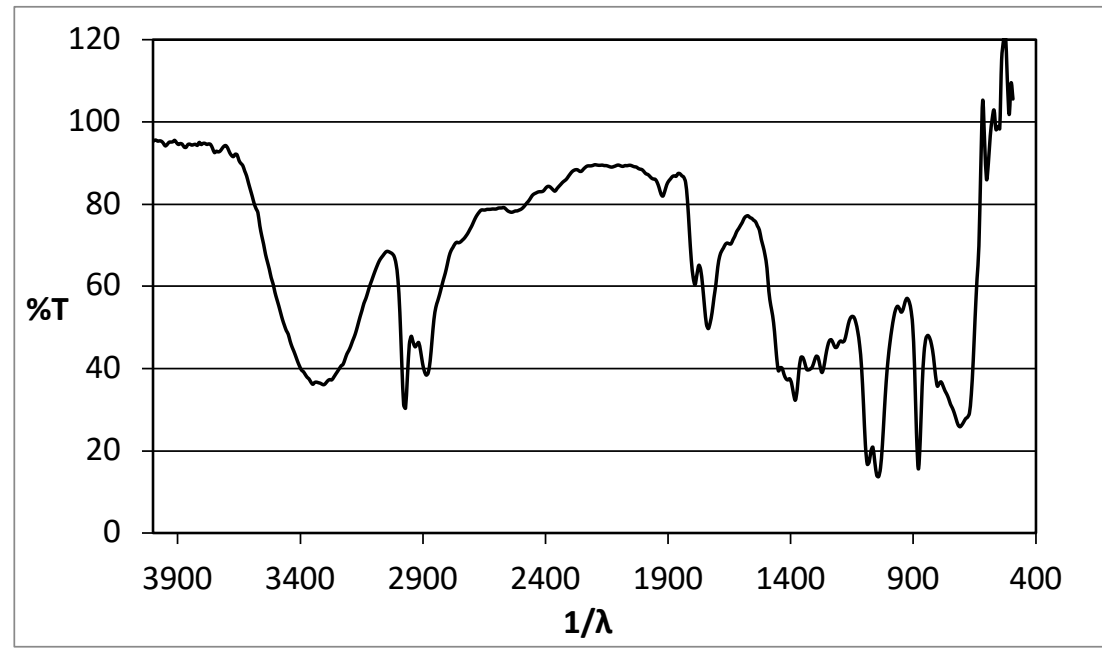

Gambar 4. Grafik FTIR 


\section{KESIMPULAN}

Dari hasil perhitungan dengan anova, terdapat pengaruh signifikan pada temperatur dan jenis pelarut terhadap kadar antosianin dan aktivitas antioksidan, sedangkan rendemen dipengaruhi oleh jenis pelarut. Kondisi optimum ekstraksi adalah pada temperatur $45^{\circ} \mathrm{C}$ dengan campuran pelarut etanol:air $(50: 50 \mathrm{v} / \mathrm{v})$, dengan perbandingan $\mathrm{F}: \mathrm{S}=1: 10$. Konstanta laju kinetika degradasi tertinggi pada pemanasan dengan temperatur $60^{\circ} \mathrm{C}$. Dari hasil analisis gugus fungsi dengan FTIR menunjukkan bahwa terdapat gugus-gugus yang identik pada senyawa antosianin bunga rosella.

\section{SARAN}

Perlu dilakukan penelitian lebih lanjut untuk mengetahui komponen lain yang terkandung pada ekstrak rosella.

\section{DAFTAR PUSTAKA}

[1] Aurelio, D.L. et al., 2008. Thermal kinetic degradation of anthocyanins in a roselle (Hibiscus sabdariffa L. cv. 'Criollo') infusion. International Journal of Food Science and Technology, pp. 322-325.

[2] Boeing, J. S. et al., 2014. Evaluation of solvent effect on the extraction of phenolic compounds and antioxidant capacities from the berries: application of principal component analysis. Chemistry Central Journal, pp. 1-9.

[3] Chumsri, P., Sirichote, A. \& Itharat, A., 2007. Studies on the optimum conditions for the extraction and concentration of roselle (Hibiscus sabdariffa Linn.) extract. Songklanakarin Journal of Science and Technology, pp. 133-139.

[4] González, C. S., Balderas, T. V. F., Regules, A. E. O. \& Beltrán, J. Á. G., 2012. Antioxidant properties and color of Hibiscus sabdariffa extracts. Ciencia e Investigacion AGRARIA, pp. 7990.

[5] Hadi, Humam T. \& Ahmed R., 2017. Extraction and determination of anthocyanin pigment from Hibiscus sabdariffa calyx by the use of UV and HPTLC method. World Journal of Pharmacy and Pharmaceutical Scinces, vol 6, pp. 130-135.

[6] Lase, I., 2013. Uji Aktivitas Antioksidan Ekstrak Etanol Beras merah (Oryza sativa L. var Kuku Balam Merah) dengan Berbagai Cara Pemasakan, Medan: s.n.

[7] Mahmudatussa'adah, A., Fardiaz, D., Andarwulan, N. \& Kusnandar, F., 2014. Karakteristik Warna dan Aktivitas Antioksidan Antosianin Ubi Jalar Ungu. Jurnal Teknologi dan Industri Pangan, pp. 176-184.

[8] Mohamed, Rasha K. et al., 2016. Extraction of anthocyanin pigments from Hibiscus sabdariffa L. and evaluation of their antioxidant activity. Middle East Journal of Applied Sciences, vol 6, pp. 856-866.

[9] Oancea, S., Stoia, M. \& Coman, D., 2012. Effects of extraction conditions on bioactive anthocyanin content of Vaccinium corymbosum in the perspective of food applications. Procedia Engineering, pp. 489-495.

[10] Sayuti, K. \& Yenrina, R., 2015. Antioksidan Alami dan Sintetik. Padang: Andalas University Press.

[11] Sipahli, S., Mohanlall, V. \& Mellem, J. J., 2016. Stability and degradation kinetics of crude anthocyanin extracts from H. sabdariffa. Food Science and Technology.

[12] Wu, Hai Yao, et al., 2018. Roselle Anthocyanins: Antioxidant Properties and Stability to Heat and $\mathrm{pH}$. Molecules, 23. 